\title{
Automated Conversion of English and Hindi Text to Braille Representation
}

\author{
Manzeet Singh \\ Master of Engineering \\ Computer science \& Engineering, \\ Thapar University, Patiala, Punjab
}

\author{
Parteek Bhatia \\ Assistant Professor, \\ Department of Computer Science \& Engineering, \\ Thapar University, Patiala, Punjab
}

\begin{abstract}
Nearly 161 million persons live with a disabling visual impairment, of whom 37 million are blind. About 90\% of them live in developing countries of Africa, Asia, Latin America and the Pacific Regions. 9 out of 10 blind children in developing countries have no access to education. The system of embossed writing invented by Louis Braille gradually came to be accepted throughout the world as the fundamental form of written communication for blind individuals. This paper is concerned about the transliteration of English and Hindi text to Braille. Braille is a dotted pattern used by the blind people for reading and writing. In this paper we have discussed the possible ways to teach Blind people [11].
\end{abstract}
1) Audio
2) Braille

The problems with the particular pattern and which approach is better is also discussed .In this transliteration we have used a chart as database, from where we have done mapping for the corresponding Braille representation ,then implementation ,testing of the system and future scope are discussed. English to Braille conversion responds to increased demands on the Braille code that is integrated education of blind children; great diversity of presentation techniques used in printed textbooks; computer aided translation from print to Braille; globalization underpinning resource sharing and the widespread use of English as a second or further language. The change inherent in English to Braille transliteration is mostly minor for literary Braille and most evident for mathematics and science notation making Braille easier to learn by all stakeholders and easier to read and write for blind people. English to Braille Transliteration is optimized for use by students integrated into regular schools; ideal for students using English as their primary and secondary language; and well -suited to the needs of blind students in developing countries.

\section{Key words}

Braille cell, Bharati Braille, Braille alphabet.

\section{INTRODUCTION}

Braille is a system of writing that uses patterns of raised dots to inscribe characters on paper. It therefore allows visually impaired people to read and write using touch instead of vision. It is the way for blind people to participate in a literate culture. First developed in the nineteenth century
.Braille has become the pre-eminent tactile alphabet. Its characters are six- dot cells, two wide by three tall. Any of the dots may be raised, giving 64 possible characters [6]. Although Braille cells are used world-wide, the meaning of each of the 64 cells depend on the language that they are being used to depict. Different languages have their own Braille codes, mapping the alphabets, numbers and punctuation symbols to Braille cells according to need. Braille characters can also be used to represent whole words or group of letters. Then this text can be transliterated into Braille for output to Braille printer or directed to special Braille output devices. The Braille cell can be shown as in figure $1[8,7]$.

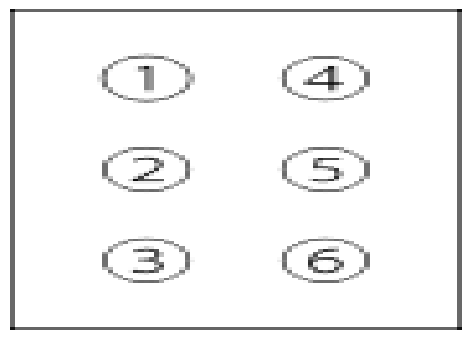

Figure 1: Braille cell

\subsection{Braille versus Audio,Visual techniques}

Braille has come under attack in recent years, with studies showing decreasing usage due to changing patterns of education. Alternative technologies, like speech synthesis ,now exist for many of its application. It can be safely assumed that sighted people will use ink printed,and visually impaired, partially sighted or blind people will used embossed pattern. There are fundamental reasons for continunig with Braille. Reading and writing Braille code is a form of literacy, literacy is a vital component of modern knowledge and society, the braille code permits literacy for blind people. Using audio only technology denies electricity to braille users.

1. Braille code is silent alternative technolgy to braille may not be usable in old circumstances. A speech synthiszer and speech interpretor forbid complete priracy and include on the local environment. They should not be appropriate in, for ex., an office environment.

2. Braille code is accurate in reading. speech synthesis, an alternative to braille may produce indecipherable meanings. 
Problem will arise from words not known to synthesizer, misspelled words or with words prononced differently according to contexts. ( e.g. the book was not read because I wanted to read it later.), reading straight from the text remove the potential source of error.

3. Braille code allows the interpretation of the text by the reader, not by another. Any reader who wishes to interpret the text themselves. -an actor or a reader for pleasure. One may want to form their own interpretation of text, not be forced into that of a disinterested computer program or particular actor. Inaccuracies in interpretation will be possible $[2,11]$

4. Braille code is cheaper than computer technology. This is a simplification. The mechanism to print and reproduce braille is expensive and the volume produce a text and braille computer transliteration. [14]

\section{ISSUES IN COMPUTERIZATION OF BRAILLE}

In Standard English Braille, many of the sixty three cells will correspond to a letter of the Roman alphabet, or a punctuation mark. A few cells called contraction will represent short words or syllables that are frequently encountered in English. When we convert English text to Braille then the following chart is used as the database and the input text is matched for the corresponding Braille representation and if the character matches the corresponding Braille is displayed. Input and output window will look like this when the text is converted to Braille. Conversion of English and Hindi text is shown in figure 2 and figure 3 [9].

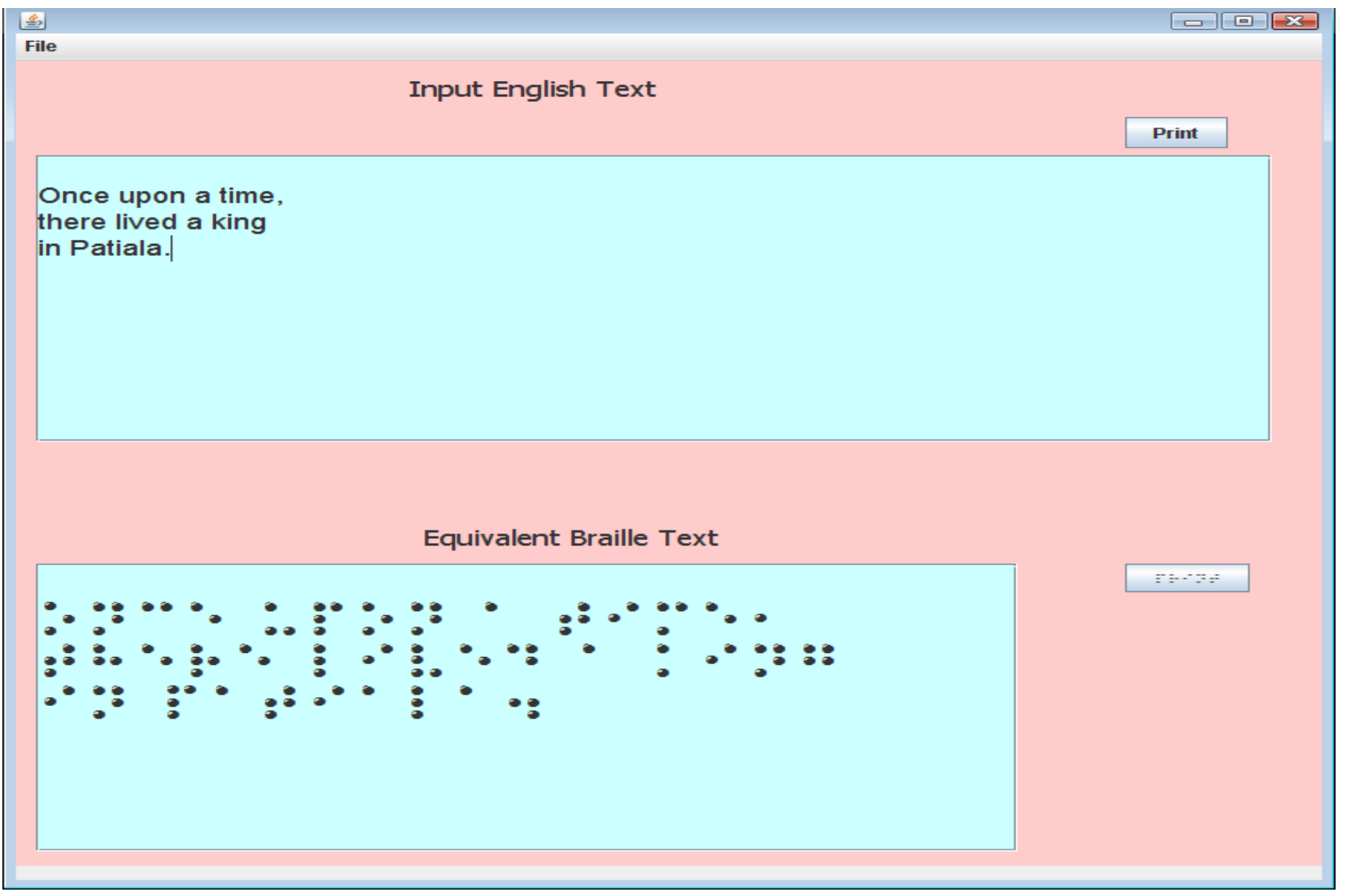

Figure 2: Input and output window for English text translation 
Table 1: Look-up tables

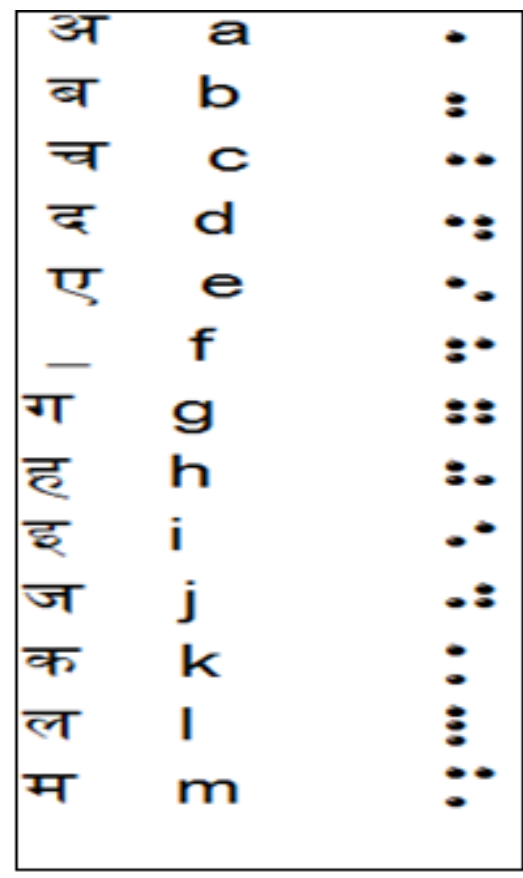

\begin{tabular}{|c|c|c|}
\hline म्म & $\mathrm{m}$ & \\
\hline न & $\mathrm{n}$ & \\
\hline अना & 0 & $=$ \\
\hline प & $P$ & $\equiv$ \\
\hline हन & 9 & \\
\hline र & $r$ & 3 \\
\hline स्स & $S$ & $=$ \\
\hline न & $\mathbf{t}$ & $=$ \\
\hline$\Xi$ & 4 & $=$ \\
\hline व & & 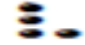 \\
\hline अा & $x$ & \\
\hline य & $y$ & \\
\hline ज्ञ & $z$ & \\
\hline$\vec{\sigma}$ & $=$ & $=2$ \\
\hline
\end{tabular}

Now when we will convert the Hindi text to Braille then the same table will be used as database and when we will enter any Hindi text .Then the letter of Hindi will be matched with the chart if any character is matched then the corresponding match of Braille is displayed as output character. The lookup table is shown above in the table 1 .

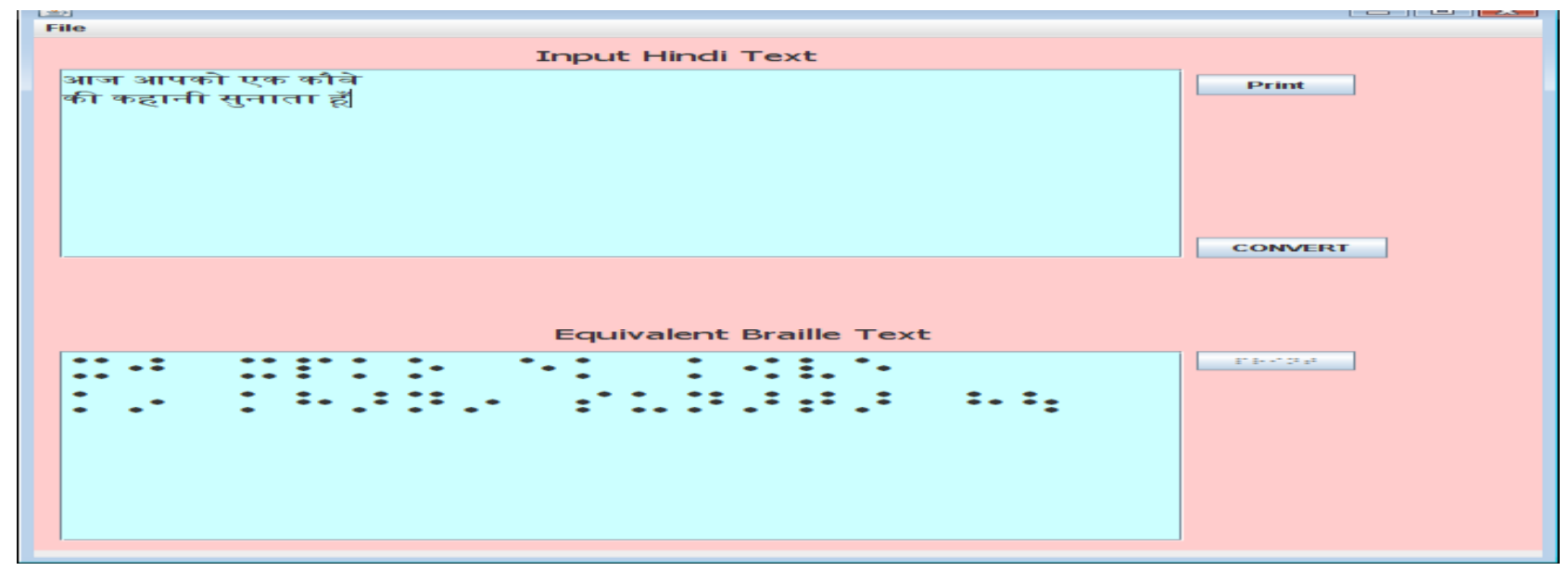

Figure 3 : Input and output window for Hindi text translation

\section{IMPLEMENTATION}

The steps which are followed when any English or Hindi text is converted into braille are as follows
1. Read a character string.

2. Separate the words on the basis of blank space.

3 . Break the corresponding word into corresponding letters 
4. Access look -up table for matching of characters of input string with look -up table characters.

5. If characters match, then print corresponding Braille character as it is.

6. Repeat steps 4 and 5 until all the characters of input string are matched with look -up table characters.

On following the steps mentioned above we will be able to convert English and Hindi text to Braille. This conversion is totally based on pattern matching. When we will draw the flowchart of the above conversion then the flowchart will have the following steps as shown below. The flowchart for the system is shown in the figure 5 .

\section{TESTING OF THE SYSTEM}

For the testing of the system we have translated some Hindi and English newspapers into the corresponding Braille and we found that it is with $100 \%$ accuracy for the grade 1 Braille and is working with $99 \%$ accuracy for Hindi. The translation of English text to Braille is shown below in the figure 4.

Dambulla: They say fix your eyes on perfection and you make almost everything speeds towards it. Sn tat Lanka's Farveez Maharoof struck to this :" Lanka's Farveez Maharoof struck to this . theory and produced a sensational hat- : : : trick to break the Indian batting lineup. : The impact of his deadly spell was such that it helped Sri Lanka to comfortably outplay India by seven wickets in the last league game of the Asia Cup at the Rangiri Dambulla International stadium

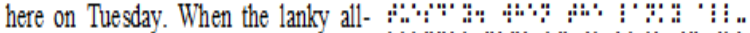
rounder came on to bow in the 30th ounder came over, just after Indian skipper MS Dhoni was run out, India were in a rather strong position at 189 for five. But the paceman unleashed a deadly over claiming his first hat-trick that brought the curtains down on Indian innings at a paltry 209, the last five wickets yielding : ': just 20 runs. In reply, Sri Lanka rounded un the match with 75 balls to spare up the match with 75 balls to spare. India will take on the same opposition in $: 1.9$ the Asia Cup final on Thursday.

Figure 4:Braille translation of English newspaper text to Braille

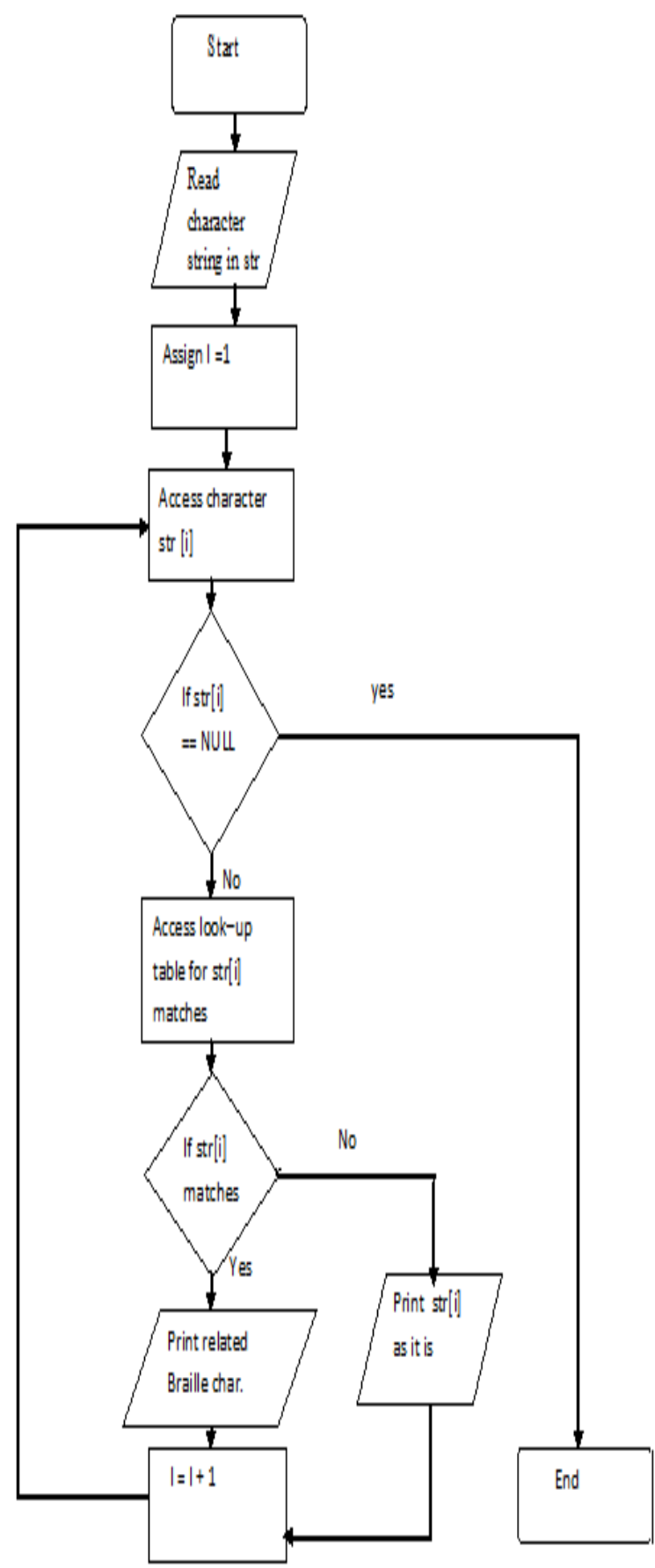

Figure 5: flowchart of the System 


\section{CONCLUSION AND FUTURE SCOPE}

This way we have made a software that will convert Hindi and English text to grade 1 Braille with the help of this software in future by having taken printout by printer and we would be able to enlighten the dark life of blinds because this conversion of text to Braille will be very fast and by this transliteration we will be able to provide enough literature to visually impaired people and they will have all that knowledge which they should have.

In future we can integrated this software for the other regional languages (Punjabi, Malayalam etc) of India. The other integration that can be done is that it can be improved also for grade 2. The integration for other Indian Languages can be done easily because Indian languages are phonetic in nature and Braille character assigned for different characters across Indian languages are nearly same. When this software would be integrated for other regional languages of India also then the barrier of Indian languages will be eliminated because then everyone can access that Braille. In future with the help of this software we can covert Indian epics to Braille so Blind people can have also access to these holy epics.

\section{REFERENCES}

[1]. J. K. Dupress and D. M. B. Baumann, "Towards making Braille as accessible as print," Dept. of Mech. Engrg., Massachusetts Institute of Technology, Cambridge, Mass., Rept. DSR 70249-1, June 19, 1968.

[2]. J. Y. Gill, "Electromechanical tape brailler," S.B. thesis, Dept. of Elec. Engrg., Massachusetts Institute of Technology, Cambridge, Mass., June 1965.

[3]. M. Lichtenstein, "The MEDCOMP Brail program," in Computer Work for the Blind. College of Medicine, University of Cincinnati, Cincinnati, pp. 23-27, September 1963.
[4]. J. Boyer, "Brailletran: A comprehensive Braille transcription program," 1966 Proc. Braille Res. Develop. Conf. (sponsored by the Sensory Aids Evaluation and Develop. Center, Massachusetts Institute of Technology, Cambridge, Mass., November 18, 1966), pp. 10-13.

[5]. E. L. Glaser, "Small computers and grade 2 Braille," 1966 Proc. Braille Res. Develop. Conf. (sponsored by the Sensory Aids Evaluation and Develop. Center, Massachusetts Institute of Technology, Cambridge, Mass., November 18, 1966), p. 14.

[6]. Bharati Braille URL

http://acharya.iitm.ac.in/disabilities/bh_brl.php.

[7]. Willonghby, Doris M; and Dufly, Sharon L. (1989): Handbook for Itinerant and Resource Teachers of Blind and Visually Impaired Students, Baltimore: National Federetion of the Blind, P. 532.

[8]. Ebnet, Matthew (2001), "Braille Challenge Gives Young Blind Students a Chance to Shine", Los Angeles Times, http://articles.latimes.com/2001/jun/30/local/me16960, retrieved 2009-04-15.

[9]. P. B. Denes, "The human use of computing machines," Bell Telephone Laboratories, Inc., Murray Hill, N. J., June 20-21, 1966.

[10].T. H. Bunnell, D. M. Yarrington, and J. B. Polikoff, "STAR: articulation training for young children," in International Conference on Spoken Language Processing, 2000.

[11].Blenkhorn, paul [ble 1997], "A System for converting print into Braille ", IEEE Transaction on Rehabilitation Engineering, Vol. 3, No .2, pp.215-221, June 1997.

[12].B. Lowenfield and G. L. Abel, Methods of Teaching Braille Reading Efficiency of Children in Lower Senior Classes. Birmingham, Research Centre for the Education of the Visually Handicapped, 1977. 